\title{
BEACH STABILIZATION TESTS OF LANDING MATS AND PREFABRICATED MEMBRANES
}

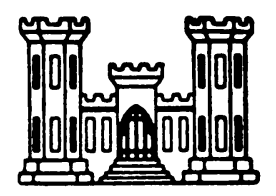

TECHNICAL REPORT NO. 3-592

February 1962

\section{U. S. Army Engineer Waterways Experiment Station} CORPS OF ENGINEERS

Vicksburg, Mississippi 